\title{
Photosynthetic parameters and growth in seedlings of Bertholletia excelsa and Carapa guianensis in response to pre-acclimation to full sunlight and mild water stress
}

\author{
Gracilene Fernandes da COSTA AZEVEDO ${ }^{1}$ \\ Instituto Nacional de Pesquisas da Amazônia - INPA, Programa de Pós-Graduação em Botânica. Av. André Araújo, 2936, Petrópolis, CEP: 69080-971. \\ Manaus, Amazonas, Brazil. gracilene_costa@yahoo.com.br
}

\begin{abstract}
Light and water are important factors that may limit the growth and development of higher plants. The aim of this study was to evaluate photosynthetic parameters and growth in seedlings of Bertholletia excelsa and Carapa guianensis in response to pre-acclimation to full sunlight and mild water stress. I used six independent pre-acclimation treatments $(0,90(11 \mathrm{~h} 15$ 12h45), 180 (10h30-13h30), 360 (09h00-15h00), 540 (07h30-16h30) and $720 \mathrm{~min}$ (06h00-18h00)) varying the time of exposure to full sunlight (PFS) during 30 days, followed by whole-day outdoor exposure for 120 days. Before PFS, the plants were kept in a greenhouse at low light levels $\left(0.8 \mathrm{~mol} \mathrm{~m}^{-2}\right.$ day $\left.{ }^{-1}\right)$. The PFS of 0 min corresponded to plants constantly kept under greenhouse conditions. From the beginning to the end of the experiment, each PFS treatment was submitted to two water regimes: moderate water stress (MWS, pre-dawn leaf water potential $\left(\Psi_{L}\right)$ of -500 to $\left.-700 \mathrm{kPa}\right)$ and without water stress (WWS, $\Psi_{\mathrm{L}}$ of $-300 \mathrm{kPa}$, soil kept at field capacity). Plants under MWS received only a fraction of the amount of water applied to the well-watered ones. At the end of the 120-day-period under outdoor conditions, I evaluated light saturated photosynthesis $\left(A_{\max }\right)$, stomatal conductance $\left(g_{s}\right)$, transpiration $(E)$ and plant growth. Both $A_{\max }$ and $g_{s}$ were higher for all plants under the PFS treatment. Stem diameter growth rate and $A_{\max }$ were higher for $C$. guianensis subjected to MWS than in well-watered plants. The contrary was true for B. excelsa. The growth of seedlings was enhanced by exposure to full sunlight for 180 minutes in both species. However, plants of $B$. excelsa were sensitive to moderate water stress. The higher photosynthetic rates and faster growth of $C$. guianensis under full sun and moderate water stress make this species a promissory candidate to be tested in reforestation programs.
\end{abstract}

KEYWORDS: Amazonia, forest tree species, photosynthesis, stomatal conductance

\section{Parâmetros fotossintéticos e crescimento em mudas de Bertholletia excelsa e Carapa guianensis em resposta a pré-aclimatação a pleno sol e estresse hídrico moderado}

\begin{abstract}
RESUMO
A luz e a água são importantes fatores que limitam o crescimento e o desenvolvimento das plantas. O objetivo deste estudo foi avaliar os paâmetros fotossintéticos e o crescimento em mudas de Bertholletia excelsa e Carapa guianensis em resposta a préaclimatação à luz solar plena e estresse hídrico moderado. Foram usados seis independentes tratamentos de pré-aclimatação a pleno sol (PFS), sendo estes de (0, 90 (11h15-12h45), 180 (10h30-13h30), 360 (09h00-15h00), 540 (07h30-16h30) e $720 \mathrm{~min}$ (06h00-18h00)) durante 30 dias seguidos por um período de exposiçáo a pleno sol de 120 dias durante o dia todo. Antes da PFS, as plantas foram mantidas em casa de vegetaçáo a baixos níveis de luz $\left(0,8 \mathrm{~mol} \mathrm{~m}^{-2} \mathrm{dia}^{-1}\right)$. $\mathrm{O} \mathrm{PFS}$ de $0 \mathrm{~min}$ correspondeu às plantas mantidas constatemente na casa de vegetação. Cada tratamento de PFS foi submetido desde o início até o final do experimento a dois regimes hídricos, denominado de estresse hídrico moderado (MWS, potencial hidrico da folha medido antes do amanhecer $\left(\Psi_{\mathrm{L}}\right)$ de $-500 \mathrm{a}-700 \mathrm{kPa}$ ) e sem estresse hídrico (WWS , $\Psi_{\text {de }}-300 \mathrm{kPa}$, solo mantido na capacidade de campo). As plantas do tratamento MWS receberam apenas uma fraçáo do volume de água fornecido para aquelas do tratamento WWS. No final do período de 120 dias foi avaliada a fotossíntese saturada por luz $\left(A_{\max }\right)$, a condutância estomática $\left(g_{s}\right)$, transpiração $(E)$ e o crescimento. $A_{\max }$ e $g_{s}$ foram maiores em todas as plantas sob o tratamento de PFS. A taxa de crescimento em diâmetro e $A$ foram maiores em plantas de $C$. guianensis submetidas à MWS. O contrário foi observado em $B$. excelsa. $\mathrm{O}$ crescimento das mudas foi maior nas plantas expostas à luz solar em 180 minutos em ambas as espécies. Entretanto, as plantas de B. excelsa foram mais sensíveis ao estresse hídrico moderado. C. guianensis foi à especie que teve melhor desempenho fotossintético e crescimento sob estresse hídrico moderado e luz solar plena. Portanto, essa espécie tem grande potencialidade para ser testada em programas de reflorestamento.
\end{abstract}

PALAVRAS-CHAVE: Amazônia, condutância estomática, espécies florestais, fotossíntese 


\section{INTRODUCTION}

In tropical rainforests, irradiance greatly oscillates across the forest profile, with high irradiance impinging on the top of forest canopy and little light reaching the forest floor. Such variations in light intensity influence the growth of seedlings and saplings in their natural environment (Holste et al. 2011). Due to low light levels in the forest understory, saplings and seedlings grow slowly and often take decades to reach the forest canopy (Clark and Clark 2001). However, in shade acclimated seedlings, sudden exposure to full sunlight causes photoinhibition of photosynthesis and under prolonged illumination irreversible damage to the leaf tissue can occur (Krause et al. 2012). Acclimation to changes in light availability is directly related to the maximization of total carbon accumulation in response to environmental changes, so that photosynthetic acclimation to full sun light is an important ecophysiological characteristic to improve plant growth and fitness (Athanasiou et al. 2010). This adjustment is related to functional changes in leaf physiology, morphology, and plant architecture (Walters 2005), which finally leads to changes in the photosynthetic properties of a leaf (Oguchi et al. 2005).

During gas exchange, the leaf loses water vapor via transpiration $(E)$ and uptakes carbon dioxide during photosynthesis $(A)$. Thus, water use efficiency (WUE or the $A / E$ ratio) is related to both stomatal functioning and carbon assimilation (Hikosaka 2004). Thereby, growth rates and plant survival under water-deficit conditions will depend on physiological mechanisms that enhance WUE (Liu et al. 2005). Acclimation to drought involves the accumulation of osmotically compatible compounds (e.g. betaines, sorbitol, proline), via osmoregulation (Larher et al. 2009), and in some species, repeated exposure to moderate water stress improves hardiness, which may lead to photosynthetic acclimation (Matthews and Boyer 1984). Acclimation to water stress probably increases the resistance of photosystem II to the high temperatures commonly associated with dry environments (Valladares and Pearcy 1997). Because degraded lands have consistently increased over time in the Amazon region (Nepstad et al. 2008), it becomes important to know how Amazonian trees species, such as Bertholletia excelsa and Carapa guianensis may respond to sudden changes in the physical environment.

The Brazil nut (Bertholletia excelsa Humb. Bonpl, Lecythidaceae) is of major socio-economic importance in the Amazon region as its fruits are the base of an important extractive industry in the region. Brazil nut seeds (about 20 per fruit) are rich in fats (about $65 \%$ on a dry mass) and have a rather high protein content (14\%), mostly legumin and albumin (Venkatachalam and Sathe 2006). Brazil nut trees (up to $50 \mathrm{~m}$ tall) can occur throughout the Amazon basin and in the Guianas (Mori and Prance 1990). It is a gap-dependent species used for regeneration (Zuidema and Boot 2002), with an intermediate shade tolerance (Mostacedo and Fredericksen 1999). Therefore its seedlings and saplings have a greater chance of survival in well-lit environments. Found throughout the Amazon region, Crabwood (Carapa guianensis Aubl., Meliaceae) is a fast-growing species (Bauch and Dunisch 2000) and its seeds are rich in fats, which account for $40-50 \%$ of dry seed mass. It is appreciated not only by the quality of its timber, but also for the medicinal properties of the high acidity carapa oil, extracted from its seeds. Carapa oil may be employed to cure many ailments including coughs, colds, whooping cough, and skin problems. In this work, I hypothesize that the light acclimation process can be stimulated when the plant is progressively subjected to mild environmental stress. Thus, the aim of this study was to evaluate photosynthetic changes and growth in juvenile plants of B. excelsa and C. guianensis in response to acclimation to full sunlight and mild water stress.

\section{MATERIALS AND METHODS}

\section{Experimental site and plant material}

The experiment was conducted at the V8 Campus of the Instituto National de Pesquisas da Amazonia (INPA) in Manaus, Amazonas (0305’30” S, 5959’35” W) between July 2010 and December 2011. I used saplings of Bertholletia excelsa and Carapa guianensis grown from seeds. After germination the plants were kept under greenhouse conditions until the beginning of the experiment (eight months for B. excelsa and three months for $C$. guianensis; the latter specie was kept a shorter period of time in the greenhouse because it grows faster than the Brazil nut). Ambient conditions in the greenhouse were mean light intensity of $0.8 \mathrm{~mol} \mathrm{~m}^{-2} \mathrm{day}^{-1}$, temperature of $27^{\circ} \mathrm{C}$, and relative humidity (RH) of $80 \%$. In the greenhouse, the natural sunlight was attenuated by the canopy of tall trees that surrounded the facility, a $150-\mu \mathrm{m}$-clear polyethylene film (as the top cover), two layers (50\%-transmittance) of nylon net shade below the plastic film and a layer of $50 \%$-transmittancenylon net shade on the sides of the greenhouse. Plants were grown in $10 \mathrm{~L}$. polyethylene bags containing as substrate forest soil from the upper 20-cm-soil layer (90\%), sand (7\%) and vermiculite $(3 \%)$. A slow-release fertilizer $\left(1.7 \mathrm{~g} \mathrm{~kg}^{-1}\right.$ substrate, Basacote ${ }^{\oplus}$ ) was added to the substrate. When the plants of both species had an average height of $12 \mathrm{~cm}$, they were subjected to six independent pre-acclimation treatments [0 min., 90 min. (11h15-12h45), $180 \mathrm{~min} .(10 \mathrm{~h} 30-13 \mathrm{~h} 30)$, $360 \mathrm{~min} .(09 \mathrm{~h} 00-15 \mathrm{~h} 00), 540 \mathrm{~min}$. (07h30-16h30) and 720 minutes (06h00-18h00)] varying the time of exposure to full sunlight (PFS), for 30 days followed by whole-day outdoor exposure (hereinafter referred to as full sunlight) for 120 days. The PFS of 0 min corresponded to plants constantly kept 
under greenhouse conditions. During the PFS treatments (30 days), every day, after the period of exposure, the plants were returned to the greenhouse until the next day, when the PFS treatment was applied again.

From the beginning to the end of the experiment (30 days of pre-acclimation followed by 120 days under outdoor conditions), each PFS treatment was submitted to two water regimes (WR), hereinafter termed moderate water stress (MWS, pre-dawn leaf water potential $\left(\Psi_{\mathrm{L}}\right)$ of -500 to -700 $\mathrm{kPa}$ ) and without water stress (WWS, pre-dawn $\Psi_{\mathrm{L}}$ of -300 $\mathrm{kPa}$ ). The WWS treatment corresponded to soil kept at field capacity. Plants under MWS received only a fraction of the water supplied to the well-watered ones. During the experiment, leaf water potential was determined daily using psychrometric sensors (L51A, Wescor, USA), a nondestructive method. Sensors were attached to the leaf the day before (at 18h00) the pre-dawn measurement in order to obtain stable values. When $\Psi_{\mathrm{LP}}$ of MWS treatment was below the target value $(-700 \mathrm{kPa})$, the plant was watered and $\Psi_{\mathrm{LP}}$ measured again following a (previously determined) stabilization period of $30 \mathrm{~min}$. To avoid the MWS treatment from receiving the open field rainfall, the top of the bag was covered with a white plastic film, with a gap of few millimeters between the soil surface and the film to allow ventilation. The same water-proof film was only used in the WWS treatment to standardize experimental conditions. Plants of the WWS treatments were irrigated daily to keep the soil at field capacity. As additional information, and in order to compare with values obtained with the psychrometric sensors, $\Psi_{\mathrm{LP}}$ was also determined using a pressure chamber (PMS Instrument Company, Albany, OR, USA), at the end of the experiment. Finally, the soil water tension $\left(\Psi_{S}\right)$ of the MWS treatment $\left(\Psi_{\text {S-MWS }}\right)$ was estimated as the difference in $\Psi_{\mathrm{LP}}$ in both water regime treatments (i.e.: $\Psi_{\text {S-MWS }}=\Psi_{\mathrm{L}-\mathrm{MW} S}-\Psi_{\mathrm{L}-\mathrm{WW} \text { ) }}$ ). For the sake of simplicity, it was assumed that $\Psi_{S}$ at field capacity is nil.

The photosynthetically active radiation (PAR), temperature ( $\mathrm{T})$ and relative humidity (RH) of both environments (greenhouse and outdoor conditions) were measured using specific sensors (Li-191SA, Li-Cor, NE, USA and Humitter $50 \mathrm{Y}$ Vaisala Oyj, Finland) connected to a data logger (Li1400 Li-Cor). Data were collected at intervals of 15 minutes during the experimental period. Just after the end of the outdoor exposure period (120 days), I determined the light saturated photosynthesis $\left(A_{\max }\right)$, the stomatal conductance $\left(g_{s}\right)$, the transpiration $(E)$, the leaf to air vapor pressure difference (VPD), the relative chlorophyll content, along with both the water use efficiency values (WUE, the $A / E$ ratio) and the intrinsic WUE $\left(A / g_{s}\right.$ ratio). I also determined the monthly increase in plant height (MIH) and diameter (MID) and the monthly rate of leaf production (MLP), by counting leaves in B. excelsa and leaflets in C. guianensis. Plant height (base to apex) and diameter (at $5 \mathrm{~cm}$ from the ground) were also measured.

Gas exchange data were collected using a portable gasexchange system (Li-6400, Li-Cor, Lincoln, NE, USA) from five plants per species and from two fully expanded leaves (upper half) per plant. The leaves used for gas exchange measurements were produced under outdoor conditions. It took about 10 days to collect all the photosynthesis data, and during this period, the plants were kept under outdoor conditions. Data were recorded between 08:00 and 14:00, when the stomata were open. Gas exchange measurements were taken at a temperature of $27 \pm 1{ }^{\circ} \mathrm{C}$, $\mathrm{RH}$ of $70 \pm 2 \%$, light intensity of $1000 \mu \mathrm{mol} \mathrm{m} \mathrm{m}^{-2}$ (light saturation) and $\left[\mathrm{CO}_{2}\right]$ of $380 \mu \mathrm{mol} \mathrm{mol}^{-1}$. The relative chlorophyll content was determined using a chlorophyll meter (SPAD-502, Minolta, Japan). Specific leaf area (SLA) was calculated as the area to leaf mass ratio. Leaf area was determined with a leaf area meter (LI-3050, Li-Cor), whereas leaf mass was assessed only after oven-drying at $72{ }^{\circ} \mathrm{C}$ until constant mass was achieved. Stem diameter was determined using digital calipers. MID and MIH were calculated as the difference between stem diameter (D) or height $(\mathrm{H})$ at the end $\left(\mathrm{t}_{2}\right)$ and beginning $\left(\mathrm{t}_{1}\right)$ and of the experimental period divided by the growing period (e.g. $\left(D_{t}\right.$ $\left.-\mathrm{D}_{\mathrm{t} 1}\right)$ /elapsed time, in months). Leaf production was assessed counting the leaf number at one-month-interval.

\section{Statistical analyses}

The experiment was a completely randomized design with five replications (plants) and treatments arranged in a $2 \times 6 \times 2$ factorial (species (SP), PFS and WR). Data were subjected to analysis of variance (ANOVA). The PFS effect in the studied variables was examined by regression analysis. The program Sigma Plot 11.0 (Systat Software, Inc, USA) was used for statistical analyses.

\section{RESULTS}

\section{Environmental conditions during the experiment}

Under full sun PAR ranged between 13 and $24 \mathrm{~mol} \mathrm{~m}^{-2}$ day $^{-1}$, while in the greenhouse, those values ranged between 0.3 and $1.32 \mathrm{~mol} \mathrm{~m}^{-2} \mathrm{day}^{-1}$ (mean of $0.8 \mathrm{~mol} \mathrm{~m}^{-2} \mathrm{day}^{-1}$, Figure 1). Temperature and $\mathrm{RH}$ were similar in both environments; mean values were $27^{\circ} \mathrm{C}$ and $80 \%$, respectively (Figure 1). Irrespective of species, $\Psi_{\mathrm{L}}$ measured with the pressure chamber (at the end of the experimental period) confirmed the $\Psi_{\mathrm{L}}$ values obtained with psychometric sensors.

\section{Relative chlorophyll content and specific leaf area}

The relative leaf chlorophyll content differed between species (SP), PFS and WR treatments (Table 1). I also found a significant interaction between SP and WR, therefore data for each species at each WR level are shown (Figure 2 A,B). 
In both species, the highest chlorophyll levels were found under greenhouse conditions. Under outdoor conditions, plants of $C$. guianensis subjected to MWS had the highest relative chlorophyll content. SLA was higher in C. guianensis than in B. excelsa, while in the Brazil nut it was higher in the WWS treatment, mainly at low PFS values (Figure 2 C,D).

\section{Gas exchange parameters}

On average, $A_{\max }$ and $g_{\mathrm{s}}$ were higher in $C$. guianensis than in B. excelsa. They were also higher in plants exposed to outdoor conditions than in those kept in the greenhouse. Across species, $A_{\max }$ and $g_{s}$ were not affected by the water regime (Figure 3). However, for these variables the interactions between treatments were significant (Table 1), therefore data for each species at each WR and PFS treatment are shown. Except for the PFS treatment under greenhouse conditions, the lowest $A_{\text {max }}$ value was observed in $B$. excelsa subjected to the PFS treatment of $360 \mathrm{~min}$ (Figure 3A). This may be due to the low chlorophyll content observed in this treatment (Figure 2). In C. guianensis, $A_{\text {max }}$ was higher in the MWS treatment (Figure 3B), which may be related to the higher chlorophyll content observed in this species under moderate water stress (Figure 2). The lowest $A_{\text {max }}$ value observed in B. excelsa during the MWS treatment (Figure 3A) does not seem to be related to an effect of the water regime on $g_{\mathrm{s}}$, as stomatal conductance was similar in both WR treatments (Figure 3D).

In general, the correlation between $A_{\max }$ and VPD was negative, but it was only significant in well-watered plants of B. excelsa (Table 2). On average, transpiration $(E)$ was higher in C. guianensis than in B. excelsa, and irrespective of the water regime, there was no effect of PFS on $E$ values (Figure 4, Table 1). On average, WUE did not differ between species, but the effect of PFS on this parameter was significant (Table 1). In the WWS treatment, WUE was consistently higher in plants of B. excelsa exposed to outdoor conditions than in those grown in the greenhouse (Figure 4 C). In C. guianensis, WUE was higher in the majority of the PFS treatments (90$540 \mathrm{~min}$ ) subjected to moderate water stress. Intrinsic WUE was higher in B. excelsa than in C. guianensis $\left(64 \mu \mathrm{mol} \mathrm{mol}^{-1}\right.$ versus $52 \mu \mathrm{mol} \mathrm{mol}{ }^{-1}$ ) without effect of either WR or PFS (data not shown).

\section{Growth in diameter and height}

The monthly increments in diameter (MID) and height (MIH) were higher in C. guianensis than in B. excelsa. In

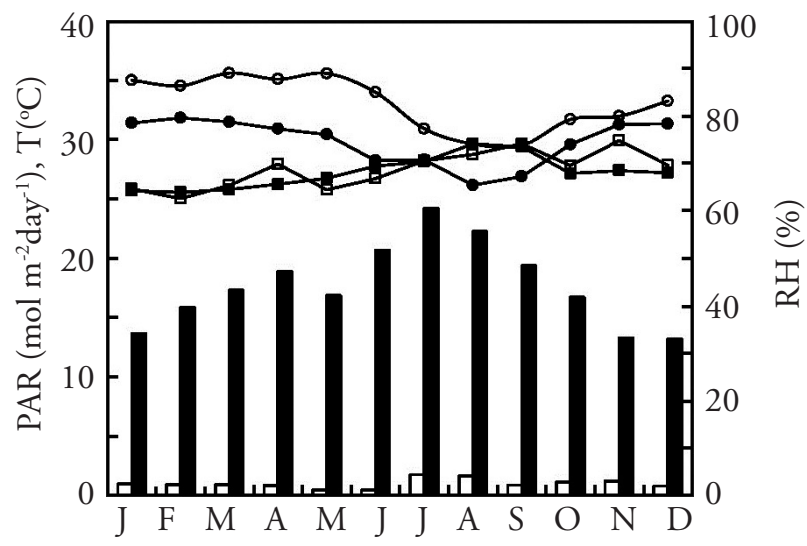

Figure 1 - Monthly average of photosynthetically active radiation (PAR, bars), temperature $(\mathrm{T}, \circ \mathrm{C}$, squares symbols) and relative humidity ( $\mathrm{RH} \%$, circles) recorded during the experimental period (July of 2010 and December of 2011). The open and dark bars indicate PAR values obtained in the greenhouse and under full sunlight, respectively. Open symbols: values obtained in the greenhouse; solid symbols, values recorded under full sunlight.

Table 1 - F values (ANOVA) for the effects of species (SP), water regime (WR) and pre-acclimation to full sunlight (PFS) on the variables: light-saturated photosynthesis $\left(A_{\max }\right)$, stomatal conductance $\left(g_{s}\right)$, leaf transpiration $(E)$, vapor pressure difference (VPD), water use efficiency (WUE), specific leaf area (SLA), SPAD values, monthly increase in height (MIH) monthly increase in diameter (MID) and monthly production of leaves or leaflets (MLP).

\begin{tabular}{|c|c|c|c|c|c|c|c|c|c|c|}
\hline Source of variation & $A_{\max }$ & $g_{s}$ & $E$ & VPD & WUE & SLA & SPAD values & $\mathrm{MIH}$ & MID & MLP \\
\hline $\mathrm{SP}$ & $40,95^{\star *}$ & $40,06^{\star *}$ & $10,84^{\star *}$ & $46,04^{* *}$ & $1,20^{\text {ns }}$ & $55,72^{\star *}$ & $215,98^{\star \star}$ & $524,04^{* *}$ & $346,89 * *$ & $106,17^{\text {** }}$ \\
\hline PFS & $10,83^{* *}$ & $2,46^{\star}$ & $1,33^{\text {ns }}$ & $4,62^{\star \star}$ & $2,43^{*}$ & $6,79 * *$ & $29,44^{* *}$ & $97,40^{\star *}$ & $29,52^{\star \star}$ & $4,73^{\star \star}$ \\
\hline WR & $0,29^{\text {ns }}$ & $0,73^{\mathrm{ns}}$ & $0,37^{\mathrm{ns}}$ & $0,21^{\mathrm{ns}}$ & $0,03^{\text {ns }}$ & $13,02^{\star *}$ & $14,85^{\star \star}$ & $11,12^{\star \star}$ & $11,14^{\star \star}$ & $7,64^{\star *}$ \\
\hline \multicolumn{11}{|l|}{ Interactions } \\
\hline SP $x$ PFS & $1,43^{\mathrm{ns}}$ & $2,03^{\text {ns }}$ & $2,18^{\mathrm{ns}}$ & $2,22^{\mathrm{ns}}$ & $1,27^{\mathrm{ns}}$ & $0,71^{\mathrm{ns}}$ & $2,18^{\mathrm{ns}}$ & $13,65^{\text {ns }}$ & $4,15^{\star \star}$ & $2,39 * *$ \\
\hline$S P \times W R$ & $3,11^{\text {ns }}$ & $3,77^{\star}$ & $3,72^{\star}$ & $0,58^{\mathrm{ns}}$ & 12,24 ** & $1,62^{\mathrm{ns}}$ & $16,56^{\star}$ & $0,82^{\star *}$ & $65,33^{\star \star}$ & $15,02^{*}$ \\
\hline PFS $\times$ WR & $1,60^{\text {ns }}$ & $0,81^{\mathrm{ns}}$ & $0,47^{\mathrm{ns}}$ & $1,17^{\mathrm{ns}}$ & $0,77^{\mathrm{ns}}$ & $0,32^{\mathrm{ns}}$ & $1,19^{\text {ns }}$ & $5,75^{\star \star}$ & $20,11^{\star \star}$ & $1,43^{\text {ns }}$ \\
\hline SP $\times$ PFS $\times$ WR & $2,44^{*}$ & $0,88^{\mathrm{ns}}$ & $2,10^{\text {ns }}$ & 4,0 ** & $3,12^{\star \star}$ & $0,31^{\mathrm{ns}}$ & $0,61^{\mathrm{ns}}$ & $7,17^{\star \star}$ & $10,19 * *$ & $2,03^{\text {ns }}$ \\
\hline
\end{tabular}

F value (ANOVA) ns, not significant ( $p>0.05)$; *, significant $(p \leq 0.05)$, and ${ }^{\star *}$, highly significant $(p \leq 0.01$, Fisher's test). 


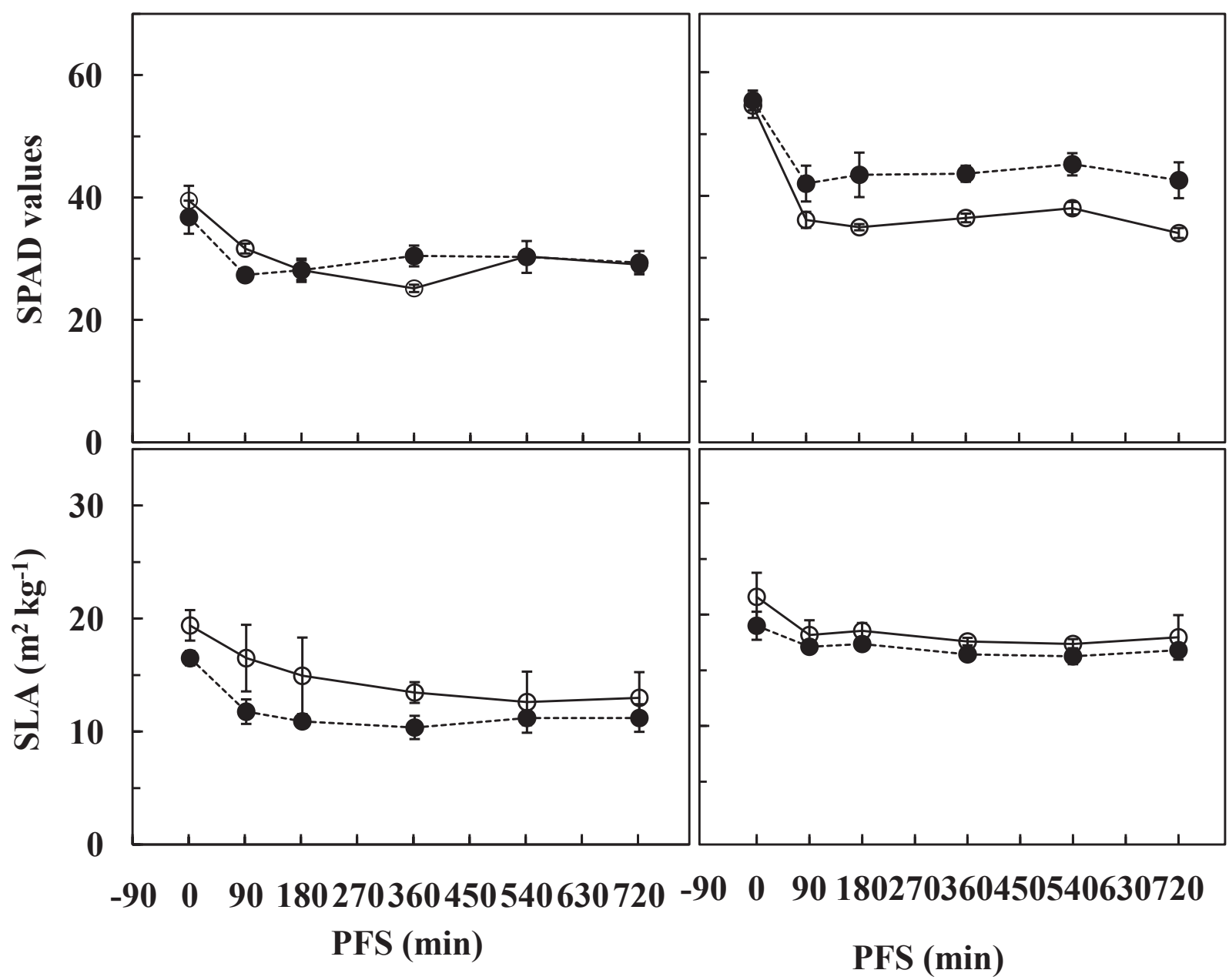

Figure 2 - Relative chlorophyll content (SPAD values) and specific leaf area (SLA) in response to pre-acclimation to full sunlight (PFS) in seedlings of $B$. excelsa $(A, C)$ and $C$. guianensis (B,D). SPAD and SLA were determined at the end of the full sunlight exposure period of 120 days. The filled symbols (dotted line) indicate plants subjected to moderate water stress (MWS) and open symbols (solid line) plants without water stress (WWS). Each symbol represents the mean of five plants and two leaves per plant $( \pm \mathrm{SD})$.

general, they were also higher in plants exposed to outdoor conditions than in those kept under greenhouse conditions (Figure 5, Table 1). As the interactions between treatments were significant (Table 1), data of the species, WR and PFS treatments are shown. In C. guianensis, higher MID values were observed in plants subjected to moderate water stress than in well-watered plants, particularly at high PFS values. The contrary was true for B. excelsa (Figure 5, Table 1). Monthly leaf production (MLP) was lower in B. excelsa than in C. guianensis, and in the latter species, it was higher under moderate water stress. MLP was also greater in plants exposed to full sun, particularly in C. guianensis (Figure $5 \mathrm{E}, \mathrm{F}$ ).
Table 2 - Correlation coefficients between light saturated photosynthesis $\left(A_{\text {max }}\right)$ and stomatal conductance $\left(g_{s}\right)$ and the vapor pressure difference (VPD) in seedlings of $B$. excelsa and $C$. guianensis determined at the end of the full sunlight exposure period of 120 days. Acronyms: Moderate water stress (MWS); without water stress (WWS). Mean of five plants and two leaves per plant.

\begin{tabular}{lllll}
\hline \multirow{2}{*}{ Variable } & \multicolumn{2}{c}{ B. excelsa } & \multicolumn{2}{c}{ C. guianensis } \\
\cline { 2 - 5 } & WWS & MWS & WWS & MWS \\
\hline$A_{\max } \times$ VPD & $-0.41^{*}$ & $-0.29^{\text {ns }}$ & $0.28^{\text {ns }}$ & $0.32^{\text {ns }}$ \\
$g_{s} \times$ VPD & $-0.06^{\text {ns }}$ & $-0.37^{\text {ns }}$ & $0.16^{\text {ns }}$ & $0.10^{\text {ns }}$ \\
\hline
\end{tabular}

ns, not significant $(>0.05),{ }^{*}$, significant $(\mathrm{p} \leq 0.05)$. 


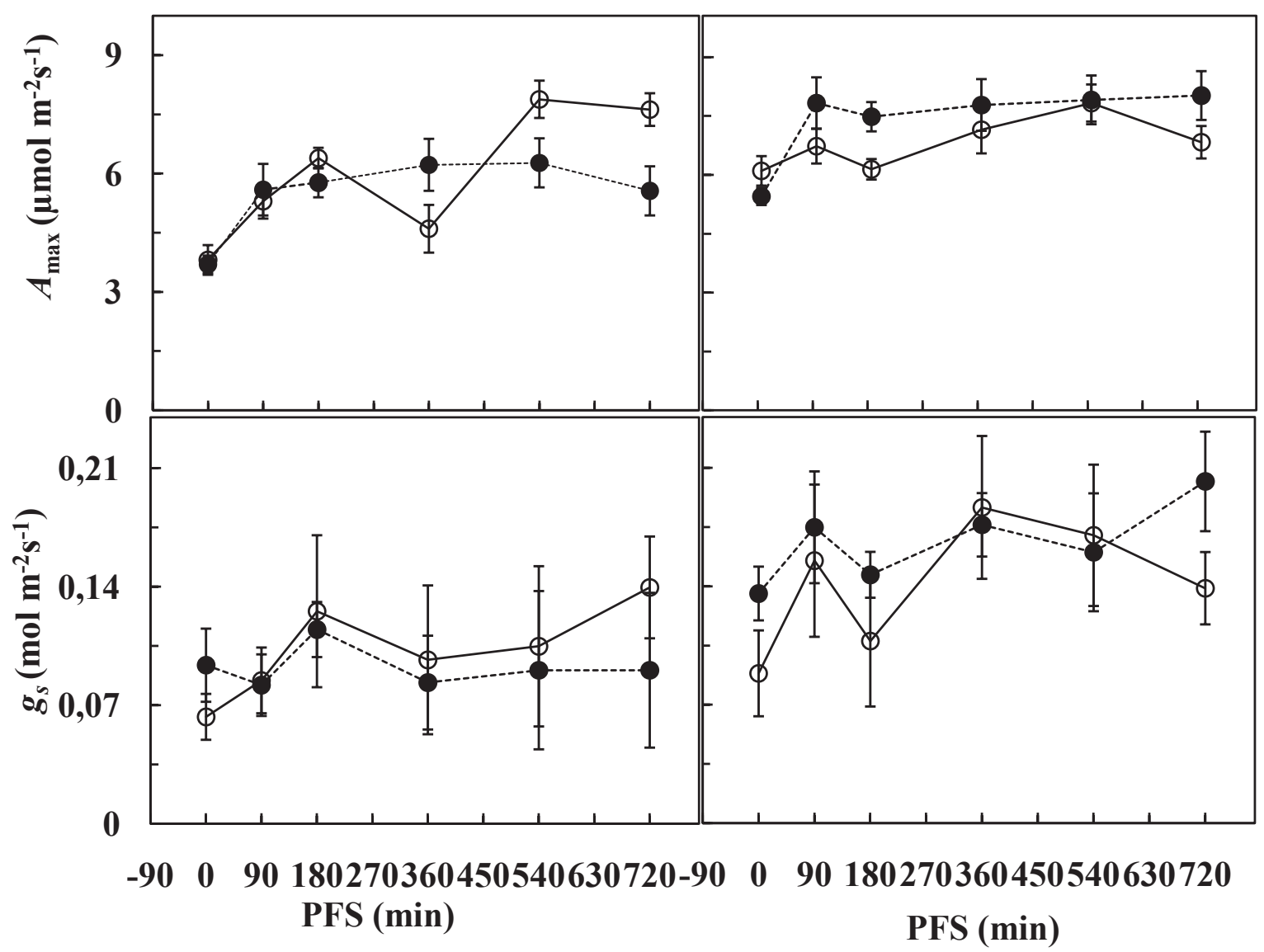

Figure 3 - Light saturated photosynthesis $\left(A_{\max }\right)$ and stomatal conductance $\left(g_{s}\right)$, in response to pre-acclimation to full sunlight (PFS) in seedlings of $B$. excelsa $(A, C)$ and $C$. guianensis $(B, D) . A_{\max }$ and $g_{s}$ were determined at the end of the full sunlight exposure period of 120 days. The filled symbols (dotted line) indicate plants subjected to moderate water stress (MWS) and open symbols (solid line) plants without water stress (WWS). Each symbol represents the mean of five plants and two leaves per plant $( \pm S D)$.

\section{DISCUSSION}

\section{Environmental conditions during the experiment}

The large variation in daily irradiance observed under full sun is not unexpected as cloudy conditions can prevail for most part of the day during the rainy season. Values of daily photon fluence recorded during this study are within the range of daily irradiance reported by others for central Amazonia (Ribeiro et al. 1982, Nascimento and Marenco 2010). As $\Psi_{\text {LP }}$ in the WWS treatment (soil at field capacity) was $-300 \mathrm{kPa}$ in both species, I concluded that there was an imbalance between the soil water tension and $\Psi_{\mathrm{LP}}$ in agreement with the findings of Donovan et al. (2001) for several species (e.g. Cornus sp., Quercus sp., Prunus persica, Betula alba). Thus, because of a lack of perfect soil-plant equilibrium (Richter 1997), it was estimated that soil water tension in the MWS treatment varied from -200 to $-400 \mathrm{kPa}$.

\section{Relative chlorophyll content and specific leaf area}

In both species, higher relative chlorophyll levels were found in plants kept in the greenhouse, corroborating that shade plants tend to increase chlorophyll concentration in order to enhance light capture (Lichtenthaler et al. 2007; Sarijeva et al. 2007). Plants of $C$. guianensis subjected to mild water stress had higher both $A_{\text {max }}$ and chlorophyll content, particularly under full sunlight. Azevedo (2013) observed that plants of $C$. guianensis under mild water stress have higher leaf $\mathrm{N}$ content, which may explain the higher chlorophyll content observed under moderate water stress, as nitrogen is required to construct antenna proteins involved in light capture (Hikosaka 2004). SLA is an important leaf trait, that has been used to predict photosynthesis (Poorter and Bongers 2006), and in both species, mild water stress and exposure to outdoor conditions led to decreases in SLA (thicker leaves). Several studies have shown that SLA tends to decrease in plants grown under full sunlight (Valladares and Niinemets 2008) 
or in plants growing under water restriction (Cunningham et al. 1999; Westoby et al. 2002).

\section{Gas exchange parameters}

The higher $A_{\max }$ values observed in C. guianensis indicate that in this species, exposure to outdoor conditions and mid water stress has a positive effect on $A_{\text {max }}$. The lower $A_{\mathrm{m}}$ values observed in $B$. excelsa subjected to the MWS treatment cannot be attributed to partial stomatal closing, not to the leaf chlorophyll content. This suggests that the biochemical properties of the leaf can be affected by the water stress, as suggested by Tezara et al. (1999). The low photosynthetic rates observed under low light intensity is in agreement with the results reported by Nascimento and Marenco (2013) for saplings grown at the forest understory under natural conditions. In Tabebuia rosea, a tropical tree, $A_{\max }$ values were 8.94 and $3.96 \mu \mathrm{mol} \mathrm{m}^{-2} \mathrm{~s}^{-1}$ in sun and shade plants, respectively (Kitajima and Hogan 2003), which is within the range reported in this study. The benefit of full sunlight acclimation on photosynthesis was also reported by others (Abrams and Mostoller 1995; Ronquim et al. 2009). Under similar environmental conditions, thicker leaves (lower SLA) have higher concentrations of Calvin cycle proteins and, consequently, higher photosynthetic rates (Evans and Poorter 2001; Nikolopoulos et al. 2002). In B. excelsa, a decrease in SLA was associated with an increase in $A_{\text {max }}$, particularly in well-irrigated plants. Several studies have shown a positive correlation between photosynthesis and specific leaf mass, the inverse of SLA (Niinemets 1999; Feng 2008).

The higher $g_{s}$ found in C. guianensis under full sunlight suggests that, in this species, PFS leads to an increase in stomatal density (Franks and Beerling 2009), which ultimately results in a high stomatal pore area (Valladares and Niinemets 2008). Irrespective of pre-exposure to full sunlight, $g_{\mathrm{s}}$ remained rather constant in B. excelsa, indicating that the positive effect of light exposure was offset by the negative effect of the water deficit, which leads to similar values of $g_{\mathrm{s}}$ in both sun and shade plants. Water restriction usually leads to reduction in

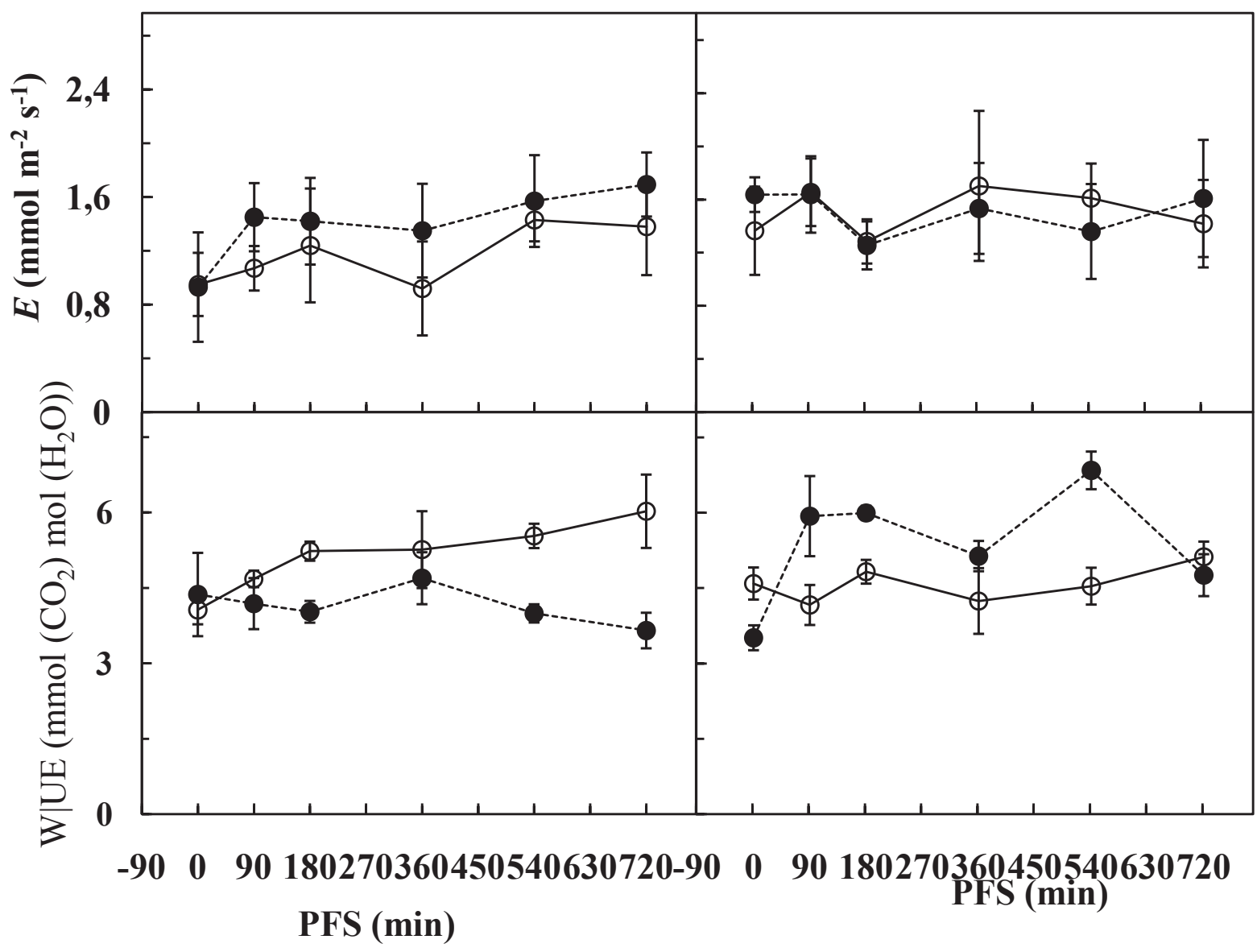

Figure 4 - Leaf transpiration (E) and water use efficiency (WUE), in response to pre-acclimation to full sunlight (PFS) in seedlings of $B$. excelsa (A,C) and C. guianensis (B,D). E and WUE were determined at the end of the full sunlight exposure period of 120 days. The filled symbols (dotted line) indicate plants subjected to moderate water stress (MWS) and open symbols (solid line) plants without water stress (WWS). Each symbol represents the mean of five plants and two leaves per plant $( \pm S D)$. 


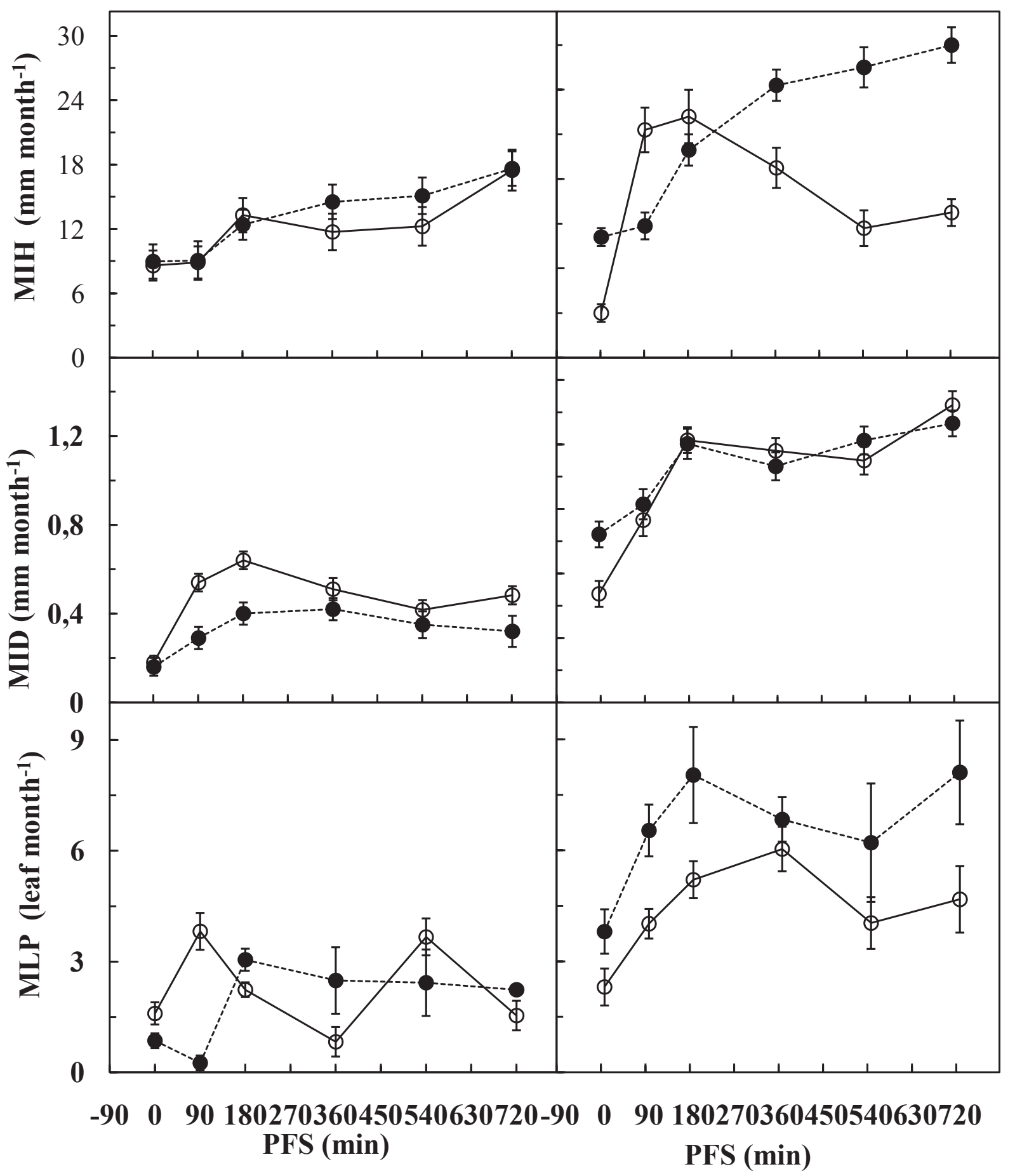

Figure 5 - Monthly increase in height (MIH), diameter (MID) and the monthly leaf production (MLP) in response to pre-acclimation to full sunlight (PFS) in seedlings of $B$. excelsa $(A, C, E)$ and $C$. guianensis (B,D,F). MIH, MID and MLP were determined at the end of the full sunlight exposure period of 120 days. The filled symbols (dotted line) indicate plants subjected to moderate water stress (MWS) and open symbols (solid line) plants without water stress (WWS). Each symbol represents the mean of five plants and two leaves per plant $( \pm S D)$. 
$g_{\mathrm{s}}$ (Valladares and Pearcy 1997; Chaves et al. 2002), and this effect was opposite to the effect of full sunlight. The lowest $g_{\mathrm{s}}$ values recorded in $B$. excelsa indicate that this species is more sensitive to water stress than $C$. guianensis. This shows that tropical species from the same region may respond differently to the acclimation process. In general, photosynthesis and $g_{\mathrm{s}}$ decreased with increasing VPD. The trend toward a decrease of $A$ and $g_{\mathrm{s}}$ with increasing VPD is consistent with results reported by others (Lio et al. 2004; Domec et al. 2009).

Distinct responses of $E$ and $g$ s to WR indicate that plants react to factors that affect water status in different ways. As can be seen in Figure 3 and 4, a low $g_{s}$ does not necessarily lead to a low $E$ value. This is because $E$ is a function of $g$ s and VPD, so that $E$ can increase when the decrease in $g_{\mathrm{s}}$ is outweighed by the increase in VPD (Dai et al. 1992; Bunce 1996; Macfarlane et al. 2004). With respect to WUE, several studies have shown that stomatal opening decreases as evaporative demand increases (Dai et al. 1992; Domec et al. 2009) which restraints $\mathrm{CO}_{2}$ diffusion into intercellular space, thereby influencing WUE.

\section{Growth in diameter and height}

In all treatments, crabwood grew faster than Brazil nut. The highest growth rate of C. guianensis can be attributed to its highest photosynthetic rates, together with higher leaf production and SLA. Plants with high SLA tend to grow faster (Poorter and Bongers 2006), perhaps because nitrogen use efficiency is higher in thinner leaves (Hokosaka 2004). Moreover, growth rates of seedlings tend to be enhanced in plants that produce larger seeds (Janos 1980), an effect that can last up to four years (Poorter and Rose 2005). Seeds of C. guianensis are larger (25 g per seed, Ferraz et al. 2002) than those of B. excelsa, 4 to $10 \mathrm{~g}$ per seed (Tonini and ArcoVerde 2004), which may contribute the faster growth of $C$. guianensis seedlings. Growth rates reported in this study concur with those observed previously, either for B. excelsa $(0.5$ $\mathrm{mm}$ month $^{-1}$, Camargo et al. 1994) or C. guianensis (0.95 to $2.2 \mathrm{~mm} \mathrm{month}^{-1}$, Bauch and Dunisch 2000, Camargo and Marenco 2012).

MID values observed in $B$. excelsa under greenhouse conditions agree with those reported by Pena-Claros et al. (2002). However, they observed higher growth rates in plants grown under full sunlight. This discrepancy can be attributed the difference in the experimental conditions, as Pena-Claros et al. (2002) used larger saplings. MIH values observed in both species are within the range reported by Azevedo and Marenco (2012) in other Amazonian species (Minquartia guianensis and Swietenia macrophylla). Taking leaf size into account [a leaflet $\left(54.8 \mathrm{~cm}^{2}\right)$ of $C$. guianensis is 1.6 times larger than a leaf of $B$. excelsa], I concluded that the total amount of foliage production was about four times higher in C. guianensis than in $B$. excelsa. Thus, the high growth rates observed in
C. guianensis under mild water stress can be attributed to its high photosynthetic rates, as well as its high leaf production, plant responses that were not observed in B. excelsa. Leaf production observed in B. excelsa during the MWS treatment is consistent with that reported by Barros and Barbosa (1995), who observed less foliage in plants of $A$. macrocarpa and $A$. farnesiana subjected to water restriction.

\section{CONCLUSIONS}

Seedlings of B. excelsa and C. guianensis have a different physiological performance. A pre-exposure time to full sunlight of $180 \mathrm{~min}$ is adequate for both species. More prolonged exposure times ( $>180 \mathrm{~min}$ under full sun) can impair plant growth. Subjecting plants to mild water stress seems to improve the acclimation response only in $C$. guianensis. In $B$. excelsa, pre-acclimation to full sun should be carried out in well-watered plants. In comparison with $B$. excelsa, higher foliage production and higher photosynthetic rates of $C$. guianensis are factors that result in faster growth of this species. The higher growth rates of $C$. guianensis suggest this species is a promissory one to be tested in field experiments under a wider range of environmental conditions.

\section{ACKNOWLEDGEMENTS}

To the Ministério da Ciência Tecnologia a Inovação MCTI/INPA, Fundação de Amparo à Pesquisa do Estado do Amazonas, FAPEAM (PIPT-1746.08/UA-062.03164.12) and Coordenação de Aperfeiçoamento de Pessoal de Nível Superior- CAPES.

\section{REFERENCES}

Abrams, M.D.; Mostoller, S.A. 1995. Gas exchange, leaf structure and nitrogen in contrasting successional tree species growing in open and understory sites during a drought. Tree Physiology, 15: 361-370.

Athanasiou, K.; Dyson, B.C.;Webster, R.E.; Johnson, G.N. 2010. Dynamic acclimation of photosynthesis increases plant fitness in changing environments. Plant Physiology, 152: 366-373.

Azevedo, G.F.C.; Marenco, R.A. 2012. Growth and physiological changes in saplings of Minquartia guianensis and Swietenia macrophylla during acclimation to full sunlight. Photosynthetica, 50: 86-94

Azevedo, G.F.C. 2013. Mudanças fisiológicas associadas à préaclimatação em quatro espécies florestais da Amazônia. Tese de Doutorado, Instituto Nacional de Pesquisas da Amazônia, Manaus-Amazonas. 115 p.

Barros, L.M.; Barbosa, D.C.A. 1995. Crescimento de Acacia farnesiana (L.) Willd. em casa de vegetaçáo. Phyton, 57: 179-191.

Bauch, J.; Dunisch, O. 2000. Comparison of growth dynamics and wood characteristics of plantation-grown and primary forest Carapa guianensis in Central Amazonia. Iawa Journal, 21: 321-333. 
Bunce, J.A. 1996. Does transpiration control stomatal responses to water vapour pressure deficit? Plant Cell and Environment, 20:131-135.

Camargo, M.A.B.; Marenco, R.A. 2012. Growth, leaf and stomatal traits of crabwood (Carapa guianensis Aubl.) in central Amazonia. Revista Árvore, 36: 07-16.

Camargo, P.B.; Salomao, R.P.; Trumbore, S.; Martinelli, L.A. 1994. How old are large Brazil-nut trees (Bertholletia excelsa) in the Amazon? Scientia Agricola, 51: 389-391.

Chaves, M.M.; Pereira, J.S.; Maroco, J.; Rodrigues, M.L.; Ricardo, C.P.P.; Osorio, M.L.; Carvalho, I.; Faria, T.; Pinheiro, C. 2002. How plants cope with water stress in the field. Photosynthesis and growth. Annals of Botany, 89: 907-916.

Clark, D.A.; Clark, D.B. 2001. Getting to the canopy: Tree height growth in a neotropical rain forest. Ecology, 82: 1460-1472.

Cunningham, S.A.; Summerhayes, B.; Westoby, M. 1999. Evolutionary divergences in leaf structure and chemistry, comparing rainfall and soil nutrient gradients. Ecological Monographs, 69: 569-588.

Dai, Z.; Edwards, G.E.; Ku, M.S.B. 1992. Control of photosynthesis and stomatal conductance in Ricinus communis $\mathrm{L}$ (Castor Bean) by leaf to air vapor-pressure deficit. Plant Physiology, 99: 14261434.

Domec, J.C.; Noormets, A.; King, J.S.; Sun, G.; McNulty, S.G.; Gavazzi, M.J.; Boggs, J.L.; Treasure, E.A. 2009. Decoupling the influence of leaf and root hydraulic conductances on stomatal conductance and its sensitivity to vapour pressure deficit as soil dries in a drained loblolly pine plantation. Plant Cell and Environment, 32: 980-991.

Donovan, L.A.; Linton, M.J.; Richards, J.H. 2001. Predawn plant water potential does not necessarily equilibrate with soil water potential under well-watered conditions. Oecologia, 129: 328335.

Evans, J.R.; Poorter, H. 2001. Photosynthetic acclimation of plants to growth irradiance: the relative importance of specific leaf area and nitrogen partitioning in maximizing carbon gain. Plant, Cell and Environment, 24: 755-767.

Feng, Y.L. 2008. Photosynthesis, nitrogen allocation and specific leaf area in invasive Eupatorium adenophorum and native Eupatorium japonicum grown at different irradiances. Physiologia Plantarum, 133: 318-326.

Ferraz, I.D.K.; Camargo, J.L.C.; Sampaio, P.T.B, 2002. Sementes e plântulas de andiroba (Carapa guianensis Aubl. e Carapa procera D. C.): aspectos botânicos, ecológicos e tecnológicos. Acta Amazonica, 32: 647-661.

Franks, P.J.; Beerling, D.J. 2009. Maximum leaf conductance driven by $\mathrm{CO}_{2}$ effects on stomatal size and density over geologic time. Proceedings of the National Academy of Sciences of the United States of America, 106: 10343-10347.

Hikosaka, K. 2004. Interspecific difference in the photosynthesisnitrogen relationship: patterns, physiological causes, and ecological importance. Journal of Plant Research, 117: 481- 494.
Holste, E.K.; Kobe, R.K.; Vriesendorp, C.F. 2011. Seedling growth responses to soil resources in the understory of a wet tropical forest. Ecology, 92: 1828-1838.

Janos, D.P. 1980. Vesicular-arbuscular mycorrhizae affect lowland tropical rain-forest plant growth. Ecology, 61: 151-162.

Kitajima, K.; Hogan, K.P. 2003. Increases of chlorophyll a/bratios during acclimation of tropical woody seedlings to nitrogen limitation and high light. Plant, Cell and Environment, 26: 857-865.

Krause, G.H.; Winter, K.; Matsubara, S.; Krause, B.; Jahns, P.; Virgo, A.; Aranda, J.; Garcia, M. 2012. Photosynthesis, photoprotection, and growth of shade-tolerant tropical tree seedlings under full sunlight. Photosynthesis Research, 113: 273-285.

Larher, F.R.; Lugan, R.; Gagneul, D.; Guyot, S.; Monnier, C.; Lespinasse, Y.; Bouchereau, A. 2009. A reassessment of the prevalent organic solutes constitutively accumulated and potentially involved in osmotic adjustment in pear leaves. Environmental and Experimental Botany, 66: 230-241.

Lichtenthaler, H.K.; Alexander, Ac.; Marek, M.V.; Kalina, J.; Urban, O. 2007. Differences in pigment composition, photosynthetic rates and chlorophyll fluorescence images of sun and shade leaves of four tree species. Plant Physiology and Biochemistry, 45: 577-588.

Lio, A.; Fukasawa, H.; Nose, Y.; Kakubari, Y. 2004. Stomatal closure induced by high vapor pressure deficit limited midday photosynthesis at the canopy top of Fagus crenata Blume on Naeba mountain in Japan. Trees-Structure and Function, 18: 510-517.

Liu, F.; Andersen, M.N.; Jacobsen, S.E; Jensen, C.R. 2005. Stomatal control and water use efficiency of soybean (Glycine max L. Merr.) during progressive soil drying. Environmental and Experimental Botany, 54: 33- 40 .

Macfarlane, C.; White, D.A.; Adams, M.A. 2004. The apparent feed-forward response to vapour pressure deficit of stomata in droughted, field-grown Eucalyptus globulus Labill. Plant Cell and Environment, 27: 1268-1280.

Matthews, M.A.; Boyer, J. 1984. Acclimation of photosynthesis to low leaf water potentials. Plantarum Physiology, 74: 161-166.

Mori, S.A.; Prance, G.T. 1990. Taxonomy, ecology, and economic botany of the Brazil nut (Bertholletia excelsa Humb. \& Bonpl.: Lecythidaceae). Advances in Economic Botany, 8: 130-150.

Mostacedo, C.B.; Fredericksen, T.S. 1999. Regeneration status of important tropical forest tree species in Bolivia: assessment and recommendations. Forest Ecology and Management, 124: 263-273.

Nascimento, H.C.S.; Marenco, R.A. 2010. SPAD-502 readings in response to photon fluence in leaves with different chlorophyll content. Ceres, 57: $614-620$.

Nascimento, H.C.S.; Marenco, R.A. 2013. Mesophyll conductance variations in response to diurnal environmental factors in Myrcia paivae and Minquartia guianensis in Central Amazonia. Photosynthetica, 51:457-464 (doi: 10.1007/s11099-013-0046-x). 
Nepstad, D.C.; Stickler, C.M.; Soares, B.; Merry, F. 2008. Interactions among Amazon land use, forests and climate: prospects for a near-term forest tipping point. Philosophical Transactions of the Royal Society B-Biological Sciences, 363: 1737-1746.

Niinemets, U. 1999. Components of leaf dry mass per area -thickness and density- alter leaf photosynthetic capacity in reverse directions in woody plants. New Phytologist, 144: 35- 47.

Nikolopoulos, D.; Liakopoulos, G.; Drossopoulos, I.; Karabourniotis, G. 2002. The relationship between anatomy and photosynthetic performance of heterobaric leaves. Plant Physiology, 129: 235243.

Oguchi, R.; Hikosaka, K.; Hirose, T. 2005. Leaf anatomy as a constraint for photosynthetic acclimation: differential responses in leaf anatomy to increasing growth irradiance among three deciduous tress. Plant, Cell and Environment, 28: 916-927.

Pena-Claros, M.; Boot, R.G. A.; Dorado-Lora, J.; Zonta, A. 2002. Enrichment planting of Bertholletia excelsa in secondary forest in the Bolivian Amazon: effect of cutting line width on survival, growth and crown traits. Forest Ecology and Management, 161: 159-168.

Poorter, L.; Bongers, F. 2006. Leaf traits are good predictors of plant performance across 53 rain forest species. Ecology, 87:1733-1743.

Poorter, L.; Rose, S.A. 2005. Light-dependent changes in the relationship between seed mass and seedling traits: a metaanalysis for rain forest tree species. Oecologia, 142: 378-387.

Ribeiro, M.N.G.; Salati, E.; Nova, N.A.V.; Demetrio, C.G.B. 1982. Radiação solar disponível em Manaus (AM) e sua relaçáo com a duração do brilho solar. Acta Amazonica, 12:339-346.

Richter, H. 1997. Water relations of plants in the field: Some comments on the measurement of selected parameters. Journal of Experimental Botany, 48: 1-7.

Ronquim, C.C.; Prado, C.H.B.A.; Souza, J.P. 2009. Growth, photosynthesis and leaf water potential in young plants of Copaifera langsdorffii Desf. (Caesalpiniaceae) under contrasting irradiances. Brazilian Journal of Plant Physiology, 21: 197-208.
Sarijeva, G.; Knapp, M.; Lichtenthaler, H.K. 2007. Differences in photosynthetic activity, chlorophyll and carotenoid levels, and in cholorophyll fluorescence parameters in green sun and shade leaves of Ginkgo and Fagus. Journal of Plant Physiology, 164: 950-955.

Tezara, W.; Mitchell, V.J.; Driscoll, S.D.; Lawlor, D.W. 1999. Water stress inhibits plant photosynthesis by decreasing coupling factor and ATP. Nature, 401:914-91.

Tonini, H.; Arco-Verde, M.F. 2004. A castanheira-do-brasil (Bertholletia excelsa): crescimento, potencialidades e usos. Boa Vista: Embrapa Roraima, 29p. (Embrapa Roraima). Documentos, 3 .

Valladares, F.; Pearcy. R.W. 1997. Interactions between water stress. Sun-shade acclimation, heat tolerance and photoinhibition in the sclerophyll Heteromeles arbutifolia. Plant, Cell and Environment, 20: 25-36.

Valladares, F; Niinemets, U. 2008. Shade tolerance, a key plant feature of complex nature and consequences. Annual Review of Ecology Evolution and Systematics, 39: 237-257.

Venkatachalam, M.; Sathe, S.K. 2006. Chemical composition of selected edible nut seeds. Journal of Agricultural and Food Chemistry, 54: 4705- 4714.

Walters, R.G. 2005. Towards an understanding of photosynthetic acclimation. Journal of Experimental Botany, 56: 435-447.

Westoby, M.; Falster, D.S.; Moles, A.T.; Vesk, P.A.; Wright, I.J. 2002. Plant ecological strategies: Some leading dimensions of variation between species. Annual Review of Ecology and Systematics, 33: 125-159.

Zuidema, P.A.; Boot, R.G.A. 2002. Demography of the Brazil nut tree (Bertholletia excelsa) in the Bolivian Amazon: impact of seed extraction on recruitment and population dynamics. Journal of Tropical Ecology, 18: 1-31.

Recebido em 07/09/2012

Aceito em 10/01/2013 
